\title{
Lipid Surrounding of Mycobacteria: Lethal and Resuscitating Effects
}

\author{
Alla A. Selishcheva ${ }^{1,2}$, Galina M. Sorokoumova ${ }^{1}$ \\ and Evgeniya V. Nazarova1,3 \\ ${ }^{1}$ Lomonosov Moscow State Academy of Fine Chemical Technology \\ ${ }^{2}$ Biology Department, Lomonosov Moscow State University \\ ${ }^{3}$ Bach Institute of Biochemistry, Russian Academy of Sciences \\ Russia
}

\section{Introduction}

Inside of the host macrophages Mycobacterium tuberculosis cells are supposed to face various hostile conditions as the result of immune response: action of reactive oxygen and nitrogen intermediates, hydrolases, increased acidity, and antimicrobial peptides activities [Russell, 2010]. However mycobacterial cells have developed certain mechanisms to resist these defenses. Transcriptome analysis of $M$. tuberculosis showed that even negligible changes of environmental factors cause considerable alterations in global gene expression profile [Boshoff, 2004; Cole, 1998]. It's important that such alterations were observed both in the presence of chemical agents (respiration inhibitors, antituberculosis drugs (ATD), ATP synthesis inhibitors), and during incubation of mycobacteria in modified conditions (medium $\mathrm{pH}$, nature of nutrient, nutrient depletion and starvation, hypoxia, exposure to nitric oxide). As the result, altered properties of the whole cell enable mycobacteria to resist these effects. For instance, increase of the incubation temperature activated synthesis of heat shock proteins which led to higher thermal resistance of the cells; exposure of mycobacteria to the acid environment induces expression of apr $A B C$ locus responsible for restructuration of lipids of the mycobacterial cell wall and storage lipids that are required for intraphagosome survival [Abramovitch, 2011; Sung N, 2004]. Low concentrations of antibiotics in cultivation medium, that don't affect the cell growth, activate genes responsible for protein pump synthesis, which provides a removal of the antibiotics from the bacterial cell. This is one of the main mechanisms of the ATD resistance. Substitution of the nutrient, e.g. substitution of glycerol to FA (free FA or as part of phospholipids (PL)), activates genes responsible for synthesis of enzymes that switch metabolism to a different pathway of nutrient utilization. In this case mycobacterial cell involves two forms of isocitrate lyase, and utilization of the nutrient in the tricarboxylic acid cycle goes through the glyoxylate shunt [Munoz-Elias, 2005]. Upregulation of the genes encoding isocitrate lyase was shown for $M$. tuberculosis cells cultivated in anaerobic conditions [Lu, 2005], for cells isolated from human lung granulomas [Fenhalls, 2002] and from infected macrophages [Schnappinger, 2003]. All these data prove glyoxylate shunt to be an essential mechanism for survival of mycobacterial cells in phagosomes inside of the host macrophage, where they 
use lipids as the main nutrient source. And besides that bacillus has designed the way to use its own lipids to control a state of the immune cell due to release of them into the macrophage internal space followed by exocytosis and transfer to nearby macrophages [Russell, 2009]. The other successful strategy for mycobacteria to survive inside of the host cells is believed to be a transition into nonreplicating dormant state so that they could resuscitate when appropriate conditions appear.

An effect of PL on growth of mycobacteria has been studied for a long time and the data obtained are insufficient and contradictory. On the one hand, phosphatidylcholine (PC) in the form of liposomes was demonstrated to serve as the nutrient source for a pathogenic strain of M. tuberculosis H37Rv, but not to effect a growth of nonpathogenic strain H37Ra [Kondo, 1976]. On the other hand, the same research group had found that lysophosphatidylcholine, formed as the result of hydrolysis of PL under action of bacterial phospholipases, suppresses mycobacterial growth [Kondo, 1985]. For Mycobacterium smegmatis (rapidly growing nonpathogenic species of the genus Mycobacterium, commonly used as a model for M. tuberculosis) an influence of PL has been poorly investigated, but it was shown that fatty acids inhibit its growth [Kanetsuna, 1985].

In the present chapter we summarize results obtained by the authors to discuss correlation between bacilli state in vitro (active cell division, inhibition of growth, dormant state, reactivation) and amount of lipid substances (secreted or added externally) in surrounding medium.

\section{An effect of lipid substances (PL and FA) on growth of mycobacterial cells in actively replicating state}

As it was mentioned above, mycobacterial cells are able to use FA as a nutrient source both in vivo, and in vitro by means of glyoxylate shunt [McKinney, 2000; Munoz-Elias, 2005]. It is well known that mycobacterial cells have lipases of various types [Deb, 2006; Mishra, 2008], as well as phospholipase A2 [Raynaud, 2002; Stonehouse, 2002], which was determined due to fully sequenced $M$. tuberculosis $\mathrm{H} 37 \mathrm{Rv}$ genome and due to separation of these enzymes. Being equipped with such enzymes mycobacteria is capable of the hydrolysis of PL with the formation of FA. Therefore primarily we investigated the influence of PL of different classes on the growth rate of pathogenic and nonpathogenic mycobacteria.

\subsection{An effect of lipids on growth and susceptibility to ATD of $M$. smegmatis mc $^{2} 155$}

At first we used rapidly growing nonpathogenic $M$. smegmatis mc $^{2} 155$ as the model of $M$. tuberculosis. We have cultivated the cells in medium with or without PL (PC, cardiolipin $(\mathrm{CL})$ to study their susceptibility to two ATD: isoniazide (INH) and rifabutin (RFB). Growth curve measured as optical density (wavelength $600 \mathrm{~nm}$ ) of the cultivation medium (meatpeptone broth (MPB)) during growth of mycobacteria for 48 hours is represented in fig. 1 . When PC and PC/CL (1:4) liposomes (large unilamellar vesicles) applied, a slight stimulation of growth compared with control was observed. Moreover stimulation with pure PC was stronger than with mixture of PC/CL.

Addition of INH $(5 \mu \mathrm{g} / \mathrm{ml})$ inhibit growth of M. smegmatis cells at the beginning, which is reflected in longer lag phase but after 30 hours mycobacteria grow almost with the same rate 
as without INH. Cultivation of M. smegmatis cells with liposomal form of INH is similar at the beginning: there is no growth during first 30 hours and cell division during the later cultivation. However growth rate in the presence of liposomal form of INH was shown to be higher than in the presence of free INH. It's noteworthy that capacity of liposomes to reduce the effect of INH depends on the lipid composition of liposomes and was more pronounced for the mixture of PC/CL (1:4) compared to free PC (fig. 1). Analogous results were obtained for RFB (fig. 1). It's obvious, that RFB $1 \mu \mathrm{g} / \mathrm{ml}$ fully inhibited growth of $M$. smegmatis, and its liposomal form was less effective.

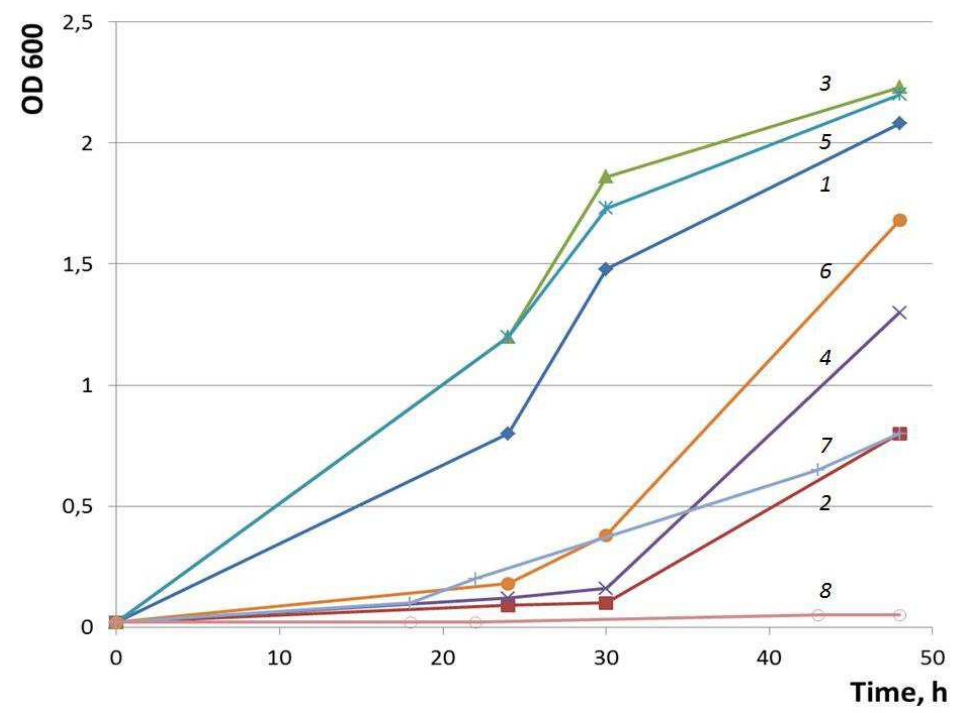

Fig. 1. A growth curve of M. smegmatis. Optical density at $600 \mathrm{~nm}$ (D600) of cultural medium (meet-peptone broth) with in control $(0,99 \% \mathrm{NaCl})(1)$ and in the presence of 2) - INH, $5 \mu \mathrm{g} / \mathrm{ml} ; 3)$ - PC, $200 \mu \mathrm{g} / \mathrm{ml} ; 4)$ - INH, $5 \mu \mathrm{g} / \mathrm{ml}+$ PC, $200 \mu \mathrm{g} / \mathrm{ml} ; 5)$ - PC/CL 1:4, $200 \mu \mathrm{g} / \mathrm{ml}$; 6) - PC/CL 1:4, $200 \mu \mathrm{g} / \mathrm{ml}+\mathrm{INH}, 5 \mu \mathrm{g} / \mathrm{ml} ; 7)$ RFB $(1 \mu \mathrm{g} / \mathrm{ml})+$ PC $(200 \mu \mathrm{g} / \mathrm{ml}) ; 8)$ RFB $(1 \mu \mathrm{g} / \mathrm{ml})$.

Thus, our data indicate that PL in culture medium decrease both ATD (INH and RFB) effect of $M$. smegmatis growth inhibition. INH and RFB have different target in mycobacterial cell: INH inhibit enzymes, responsible for elongation of fatty acid part in mycolic acids [Takayama, 1972], while RFB inhibit DNA-dependent RNA polymerase [Wehrli, 1971]. Our results allow us to conclude that there must be a general mechanism of ATD susceptibility reduction in the presence of PL for mycobacteria. This mechanism has to be realized before ATD reaches their targets.

To determinate the cause of the similar influence of PL on effect of different ATD, we investigated the growth rates of M. smegmatis in synthetic laboratory medium Sauton, and in modified analogues, in which glycerol was supplemented on other nutrient sources (acetate or PL), in the presence or absence of one of the involved ATD. We selected such concentrations of substrates that the growth rate of the samples differed slightly in the moment of ATD incorporation ( $24 \mathrm{~h}$ of cultivation). The data is represented in fig. 2 as the 
ratio (\%) between optical density of $M$. smegmatis in culture medium, containing different nutrient source in the presence of INH or RFB and control, i.e. optical density of culture medium in the absence of ATD.

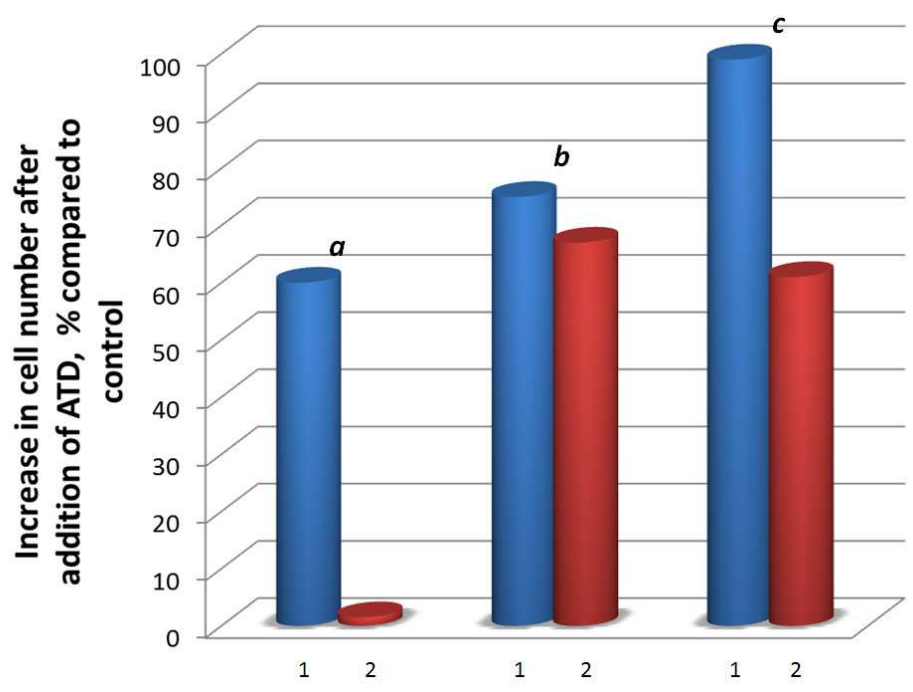

Fig. 2. Alteration of optical density of M. smegmatis cultivation medium (\% of control numbers) in the presence of ATD. 1. INH $(40 \mu \mathrm{g} / \mathrm{ml}), 2$. RFB $(7 \mu \mathrm{g} / \mathrm{ml})$ with different nutrient source: a) glycerol $(0,5 \mathrm{~g} / \mathrm{l}) ; \mathrm{b})$ acetate $(0,7 \mathrm{~g} / \mathrm{l}) ; \mathrm{c})$ PC $(1 \mathrm{~g} / \mathrm{l})$.

(Reproduced from [Shakina Y.V., 2007])

Fig.2 demonstrates, the during the growth in medium, that contains glycerol the main carbon source, $M$. smegmatis cells possess a strong resistance to INH, but are highly susceptible to RFB. In other words, when hydrocarbon substrates are utilized in full Krebs cycle, mycobacteria retain susceptibility to RFB. But when glyoxylate pathway is activated, i.e. during the growth of M. smegmatis in medium with acetate or PL as the main carbon source, mycobacteria become fully resistant to INH and susceptibility to RFB drops considerably.

It is possible, that mechanism of phenotypic resistance of M. smegmatis to two ATDs, that have different targets, may be attributed to expression of transport proteins, that are capable of binding the ATD that entered into the cell, and transport it through the cell wall out. Morris et al. [Morris, 2005] has shown that polyketide (tetracycline), macrolide (erythromycin) and aminoglycoside (streptomycine) antibiotics induce whiB7 gene of $M$. tuberculosis. Similar effect was detected when mycobacteria were cultivated with FA [Morris, 2005]. whiB7 affects tap ( $\operatorname{Rv} 1258 \mathrm{c})$, which in turn is responsible for synthesis of protein pumps that provide efflux of antibiotics out of cell. 


\subsection{An effect of lipids on growth and viability of Mycobacterium tuberculosis H37Rv}

Then we have studied a growth and viability of pathogenic Mycobacterium tuberculosis H37Rv in vitro during cultivation in liquid Dubo's medium when PL and products of their hydrolysis (lyso-components) in various concentrations were added (table 1). PL were incorporated in the cultivation medium in the form of large unilamellar vesicles. The cells were grown in atomized system BACTEC, in which the growth is detected due to the alterations in oxygen uptake level by means of fluorescent indicator, that is quenched by high oxygen concentrations (fig. 3).

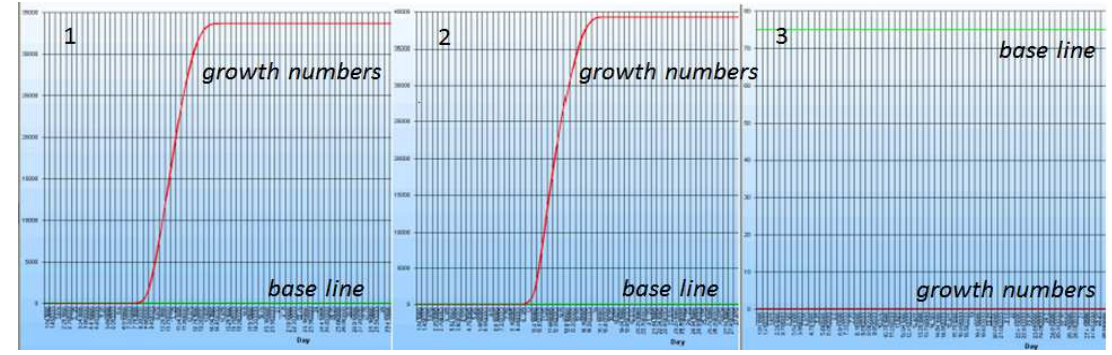

Fig. 3. Growth curves of $M$. tuberculosis $\mathrm{H} 37 \mathrm{Rv}$ in the presence of PL liposomes obtained by means of BACTEC. 1-H37Rv; 2-H37Rv+CL (50 $\mu \mathrm{g} / \mathrm{ml})$; 3-H37Rv+CL $(750 \mu \mathrm{g} / \mathrm{ml})$.

Reproduced from [Andreevskaya, 2010]

Viability of the cells was observed using colony counting on solid medium (Dubo's agar) after isolation of the passage that was exposed to the lipids in the liquid medium (fig. 4). It was found that addition of negatively-charged CL into cultivation medium had an effect on the growth rate and viability of $M$. tuberculosis H37Rv, while electro-neutral PC wasn't active. As it follows from the data shown in table 1 the effect of CL was dose-dependent: low concentration $(50 \mu \mathrm{g} / \mathrm{ml})$ caused the 1-2 day delay in growth of mycobacterial cells, and 250-330 $\mu \mathrm{g} / \mathrm{ml}$ concentration fully inhibited growth. Applying Murohashi staining method we demonstrated that such concentration of CL cause lysis of M. tuberculosis H37Rv cells (fig. 5) [Sorokoumova, 2009].

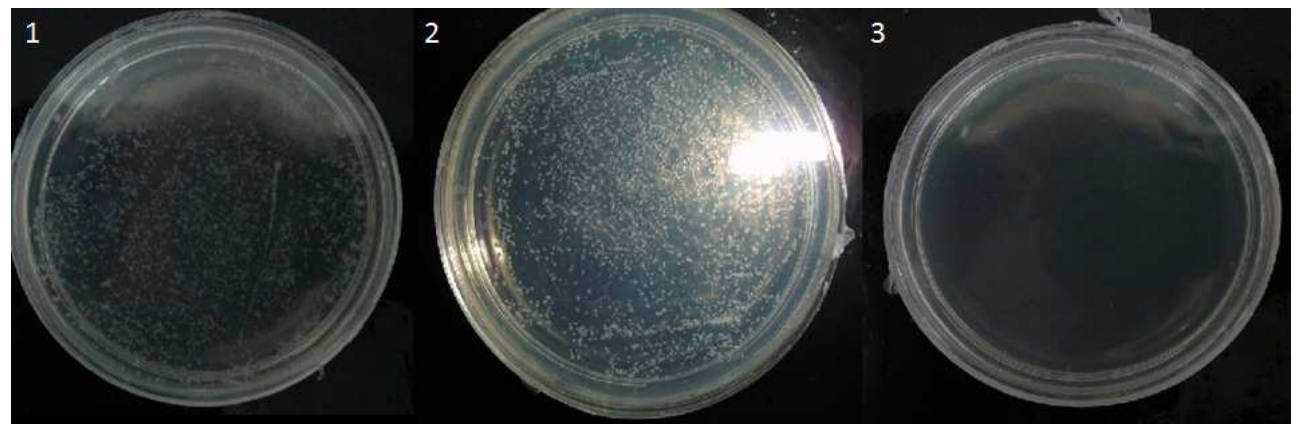

Fig. 4. A photography of macrocolonies of M. tuberculosis H37Rv on Dubo's agar by the $18^{\text {th }}$ day of cultivation. 1-H37Rv; 2-H37Rv+CL (50 $\left.\mu \mathrm{g} / \mathrm{ml}\right) ; 3-\mathrm{H} 37 \mathrm{Rv}+\mathrm{CL}(750 \mu \mathrm{g} / \mathrm{ml})$. Reproduced from [Sorokoumova, 2009] 


\begin{tabular}{|c|c|c|c|c|c|}
\hline \multirow[t]{2}{*}{ \# } & \multirow[t]{2}{*}{ Lipid } & \multicolumn{2}{|c|}{$\begin{array}{c}\text { Concentration of the } \\
\text { lipid added }\end{array}$} & \multirow{2}{*}{$\begin{array}{l}\text { The start of } \\
\text { growth, days }\end{array}$} & \multirow{2}{*}{$\begin{array}{l}\text { A presence of growth }(+) \\
\text { An absence of growth (-) }\end{array}$} \\
\hline & & $\mu \mathrm{g} / \mathrm{ml}$ & $\mu \mathrm{M}$ & & \\
\hline 1 & Control & - & - & $7-8$ & + \\
\hline \multirow[t]{4}{*}{2} & CL & 50 & 35 & $8-9$ & + \\
\hline & & 125 & 90 & $8-9$ & + \\
\hline & & 250 & & $16-18$ & $\begin{array}{c}+ \text { (considerably lower } \\
\text { than control) }\end{array}$ \\
\hline & & $300-700$ & $\begin{array}{l}200 \text { and } \\
\text { more }\end{array}$ & - & 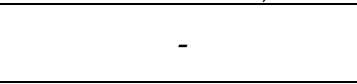 \\
\hline \multirow[t]{2}{*}{3} & LisoCL & & 35 & $7-8$ & + \\
\hline & & & 200 & $7-8$ & + \\
\hline \multirow{2}{*}{4.} & Bisliso-CL & & 35 & $7-8$ & + \\
\hline & & & 200 & $7-8$ & + \\
\hline \multirow{5}{*}{5} & Linoleic acid & & 10 & $7-8$ & + \\
\hline & & & 90 & $7-8$ & + \\
\hline & & & 200 & $14-15$ & + \\
\hline & & & 400 & 20 & + (slight growth) \\
\hline & & & 600 & - & - \\
\hline \multirow[t]{3}{*}{2} & Phosphatidic acid & & 50 & $8-9$ & + \\
\hline & & & 335 & - & - \\
\hline & & & 502 & - & - \\
\hline \multirow[t]{3}{*}{3.} & Phosphatidylglycerol & & 50 & $8-9$ & + \\
\hline & & & 335 & - & - \\
\hline & & & 502 & - & - \\
\hline \multirow[t]{3}{*}{4} & $\begin{array}{l}\text { Lisophosphatidyl- } \\
\text { glycerol }\end{array}$ & & 50 & $6-7$ & + \\
\hline & & & 335 & $2-7$ & + \\
\hline & & & $502-600$ & $2-7$ & + \\
\hline \multirow[t]{4}{*}{5.} & $\begin{array}{l}\text { Lisophosphatidyl- } \\
\text { glycerol + linoleic acid }\end{array}$ & & 50 & $5-7$ & + \\
\hline & & & 335 & $1-4,8-9$ & + \\
\hline & & & 502 & $1-4$ & - \\
\hline & & & 670 & - & - \\
\hline 6 & PC & 500 & & - & + \\
\hline \multirow[t]{3}{*}{7} & LisoPC & & 90 & $7-8$ & + \\
\hline & & & 900 & 16 & + \\
\hline & & & 9000 & 16 & + \\
\hline \multirow[t]{2}{*}{8} & $\begin{array}{l}\text { Linoleic acid and lisoPC } \\
(1: 1, \text { mole }),\end{array}$ & & 90 & $7-8$ & + \\
\hline & & & 900 & & \\
\hline
\end{tabular}

Table 1. An effect of different concentrations of PL and the products of their hydrolysis on the start and intensity of $M$. tuberculosis H37Rv growth in Dubo's medium registered with BACTEC MGIT960. 


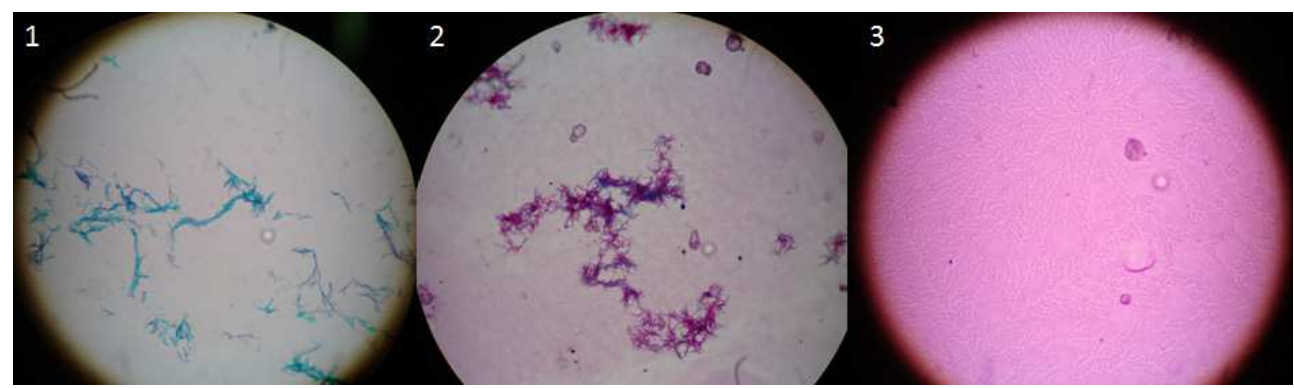

Fig. 5. Murohashi staining of $M$. tuberculosis cells (14th day of growth). 1-H37Rv; 2-H37Rv+CL (50 $\mu \mathrm{g} / \mathrm{ml}) ; 3-\mathrm{H} 37 \mathrm{Rv}+\mathrm{CL}(750 \mu \mathrm{g} / \mathrm{ml})$. Reproduced from [Mikulovish, 2010]

These data correlate well with the results of mycobacterial DNA detection by real time PCR, according to which appearance CL in culture medium didn't lead to increase of DNA number [Sorokoumova, 2009] (fig. 6).

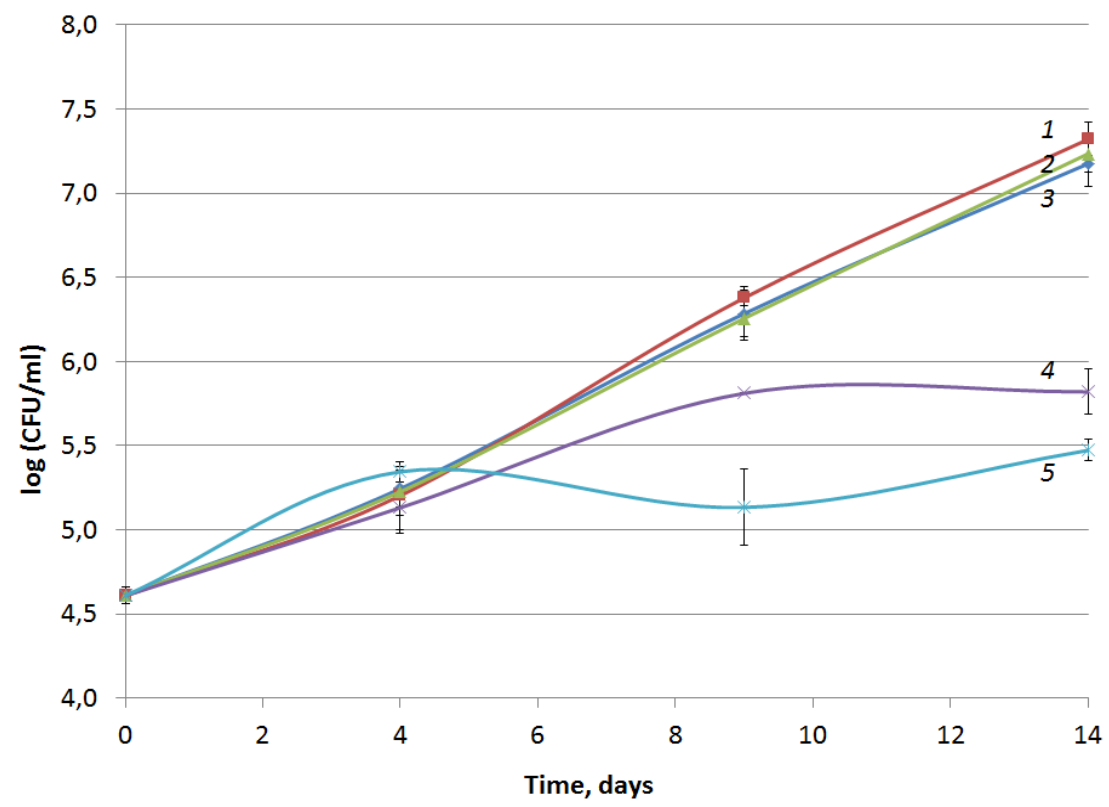

Fig. 6. Growth curves of M. tuberculosis H37Rv in Dubo's medium in the presence of CL liposomes. Growth was detected with real time PCR. 1-H37Rv; 2-H37Rv+CL $(50 \mu \mathrm{g} / \mathrm{ml})$; 3-H37Rv+CL $(250 \mu \mathrm{g} / \mathrm{ml}) ; 4-\mathrm{H} 37 \mathrm{Rv}+\mathrm{CL}(500 \mu \mathrm{g} / \mathrm{ml}) ; 5-\mathrm{H} 37 \mathrm{Rv}+\mathrm{CL}(750 \mu \mathrm{g} / \mathrm{ml})$.

Reproduced from [Sorokoumova G.M., 2009]

$\mathrm{CL}$ is an instable compound that transforms in several substances in water phase. Both in Dubo's medium, containing high concentration of iron ions, and in Tris-buffer, which doesn't have an iron, the products of hydrolysis were mainly formed: lyso-, bislysocomponents and FA (fig. 7). Along with this components such products of 
destruction as phosphatidic acid, phosphatidylglycerol, as well as the products of their hydrolysis (lysophosphatidic acid and lysophosphatidylglycerol appear in cultivation medium. Mentioned substances were isolated by preparative TLC from water phase, in which CL was cultivated without M. tuberculosis at $37^{0} \mathrm{C}$ for 4 or 6 days, and were identified by MS [Smirnova, 2011]. Summarized results of their effect on M. tuberculosis growth is represented in table 1.

1

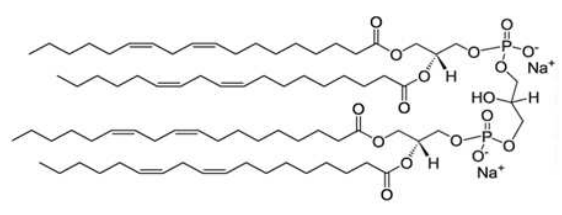

2

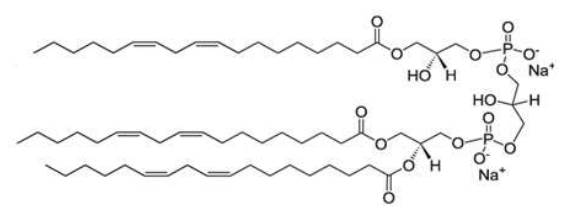

3

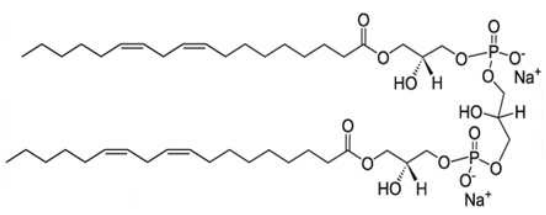

4

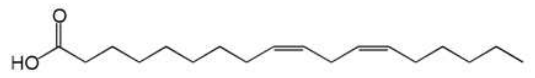

Fig. 7. Structural formulas of 1 - cardiolipin, 2 - lysocardiolipin, 3 - bislysocardiolipin, 4 - linoleic acid.

It's interesting, that lysophosphatidylglycerol, the product of phosphatidylglycerol hydrolysis, doesn't have any inhibitory activity in involved concentration interval, as well as a mixture of lysophosphatidylglycerol with linoleic acid with concentration lower than 335 $\mu \mathrm{M}$, which is inhibitory for phosphatidylglycerol. Thus, conducted experiments have shown that only negatively-charged PL (CL, phosphatidic acid, phosphatidylglycerol), but not their lysocomponents, that have negative charge as well, are able to cause the delay in growth and suppress viability of the mycobacterial cells almost in the same concentration range $(250-335 \mu \mathrm{M})$. Based on the literature one may speculate the mechanisms of negatively-charged PL activity, that inhibit the bacterial cell growth due to:

- $\quad$ their interaction with the transcription factors [Carman, 2007];

- $\quad$ an influence of CL on binding of DNA-binding A-protein, regulating interaction of ATP with mycobacterial DNA; this interaction initiate the replication of bacterial DNA [Yamamoto, 2002];

- an inhibitory effect of CL on activity of topoisomerase during binding with it in complex, which prevents cell division [Mizushima, 1992].

To conclude, the same PL seems to have various effects on the growth of different species mycobacteria. Perhaps, it may be explained by a different destiny of PL once they were introduced into 'mycobacteria space': weather they serve only as FA source, or may play a role in metabolism of microorganism by themselves. Therefore we further investigated the alterations in lipid surrounding of mycobacteria in different states: in actively replicating and nonculturable. 


\section{Role of lipid components in formation and reactivation of nonculturable mycobacterial cells}

\subsection{Mycobacterial lipids released into extracellular space during formation of dormant cells}

In vitro model of Mycobacterium smegmatis dormant state obtained due to absence of potassium ions in growth medium, created by Kaprelyants, A.S. with colleagues., let us to show that during formation of nonculturable ATD-resistant cells they lose up to $90 \%$ of their mass, which reflects in relatively balanced decrease in both lipid and protein amounts [Nazarova, 2011] (fig. 8). Nevertheless at the end of this process nonculturable cells have larger percentage of proteins rather than lipids. Qualitative lipid composition of the cells doesn't noticeably change during transition into nonculturable state with the exception of the drop of the trehalose monomycolate level. Trehalose monomycolate is a precursor of the cord-factor trehalose dimycolate, which is inherent for mycobacterial cells in all of the states.

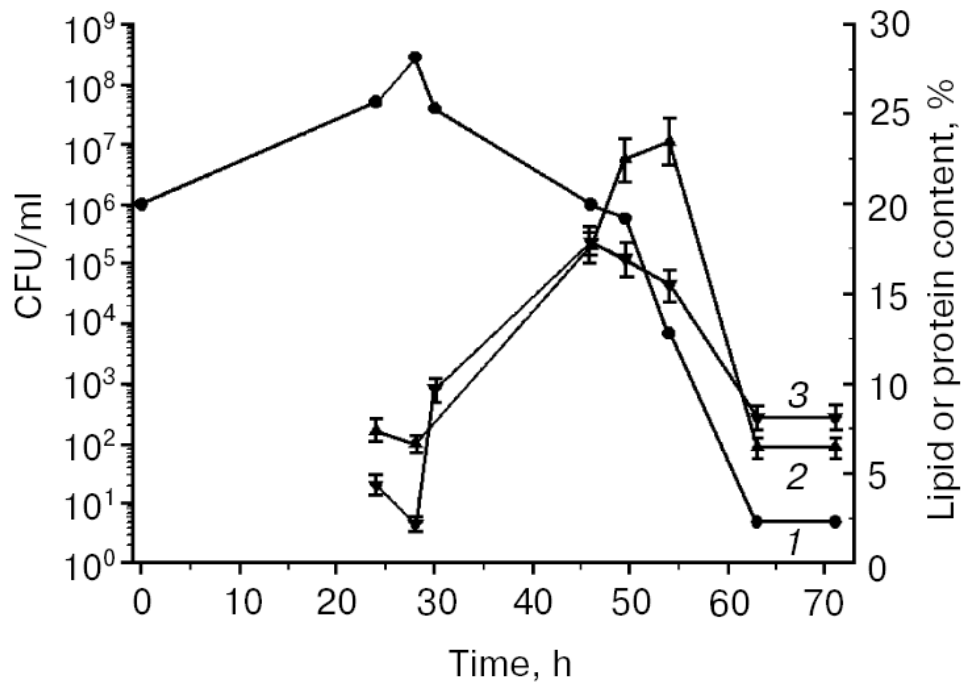

Fig. 8. Mycobacterium smegmatis growth in $\mathrm{mH}-\mathrm{deB}$ medium (1), lipid (2), and protein (3) content in cells during transition into nonculturable state depending on time based on dry biomass. Reproduced from [Nazarova, 2011].

Cell mass loss during transition into dormant state certainly might lead to appearance of detached cell lipids in surrounding medium. To detect such compounds in growth medium, we conducted a chloroform extraction of culture liquid, separated from the cells through the $200 \mathrm{~nm}$ filter and lyophilized. Nonculturable forms of $M$. smegmatis were obtained as the result of cultivation in $\mathrm{mH}-\mathrm{deB}$ medium. We used the cells, grown in nutrient and potassium ion rich Sauton's medium, for control. M. smegmatis cells upon metabolically active growth as well as upon formation of nonculturable cells release into culture liquid a considerable range of neutral lipids: FA, mycolic acids (MA), diacylglycerols (DAG), monoacylglycerols (MAG) (fig. 9). It is noteworthy that mycobacteria in none of the states don't release triacylglycerols (TAG), intracellular energy storage component. Qualitative 
lipid composition of culture liquids both in the process of active growth and during transition into nonculturable state doesn't change. However only during development of nonculturable cells level of released fatty acids enlarges twice (from $33 \mu \mathrm{M}$ to $59 \mu \mathrm{M}$ ). These data were obtained after isolation of free FA with preparative TLC and quantification of their amount with titration.

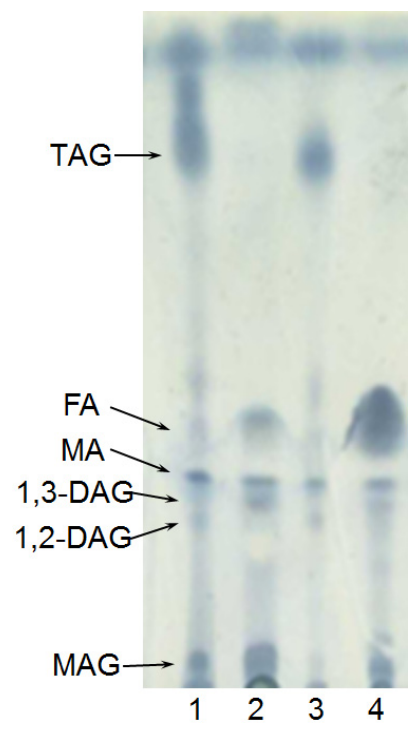

Fig. 9. TLC of lipids in system heptane-diethyl ether-acetic acid (55:45:1 v/v). Lipid extract of M. smegmatis cells cultivated for $24 \mathrm{~h}$ in Sauton's medium 1); 2) lipid extract of culture liquid of M. smegmatis cells grown for $24 \mathrm{~h}$ in Sauton's medium; 3) lipid extract of $M$. smegmatis cells cultivated for $24 \mathrm{~h}$ in $\mathrm{mH}-\mathrm{deB}$ medium; 4) lipid extract of culture liquid after cultivation of $M$. smegmatis cells for $24 \mathrm{~h}$ in $\mathrm{mH}$-deB medium. Development by phosphomolybdic acid solution with following plate heating at $100^{\circ} \mathrm{C}$. Represented from [Nazarova, 2011].

Analysis of M. smegmatis culture liquid free-FA content by GLC-MS showed that oleic acid was a prevalent component. NMR-spectra of FA isolated from a culture liquid and of the oleic acid standard appeared to be identical.

To prove a biogenic nature if the found in culture medium FA we incorporated a radioactive carbon isotope in lipids of mycobacteria as the result of [14C]aspartic acid metabolism. After addition of tagged compound to the $M$. smegmatis cells grown in $\mathrm{mH}$-deB for $46.5 \mathrm{~h}$, a part of the sample was taken for control and the rest was left to cultivate for other day at $37^{\circ} \mathrm{C}$. Gained lipid extracts of culture medium were divided on separate substance with reversephase and thin-layer chromatography. Measurement of radioactivity of different zones of TLC-plate demonstrated that in zone, corresponding to oleic acid there is an accumulation of radioactivity (12 $490 \mathrm{cpm}$ ) as compared to control sample (356 cpm). Incorporation of $\left[{ }^{14} \mathrm{C}\right]$ aspartic acid followed by accumulation of radioactivity in extracellular FA confirms that at least partially FA detected in growth medium are actually secreted. 
Level of free FA in growth medium in active state decreases (from $29 \mu \mathrm{M}$ to $5 \mu \mathrm{M}$ ), which indicates an involvement of FA in metabolism and biosynthesis of required lipids for metabolically active mycobacterial cells.

We consider complex of potassium absence and accumulation of FA in growth medium as a cause of transition of mycobacteria into dormant state in the present model. Bovine serum albumin (BSA) is conventionally required for binding of FA excess in culture liquid in laboratory experiments. When applying BSA A1470 Sigma Cohn Analog TM, mentioned FA accumulation and formation of nonculturable cells occur, whereas in case when applying Fatty Acid Free-BSA MP Biomedicals, LLC, secreted FA are entirely bound and dormant state is not achieved.

To determine the amount of FA, that were introduced initially into growth medium, we have measured the level of free FA, present in the used for experiments Tween-80, and content of the FA bound with BSA.

The mixture of low concentration Tween 80 and water was titrated with $0,014 \mathrm{M} \mathrm{NaOH}$ using $0.01 \%$ thymol blue solution as an indicator. This method let us to estimate the quantity only of free FA, not exposing an ester group for hydrolysis. FA were shown to be brought into growth medium together with Tween 80 in amount of $15 \%$ of detergent mass (table 2).

We applied a technique, based on combination of methods described by Chen, R.F., and Dole, V.P., for determination of quantity of FA bound with BSA [Chen, 1967; Dole, 1956]. Briefly: $25 \mathrm{ml}$ of extraction mixture (isopropyl alcohol : heptane : $1 \mathrm{~N} \mathrm{H}_{2} \mathrm{SO}_{4}$ (40:10:1)) were added to $5 \mathrm{ml}$ of water solution of BSA $(0,1 \mathrm{~g} / \mathrm{ml})$, shaken, let to stand for 30 minutes. Then $10 \mathrm{ml}$ of heptane and $15 \mathrm{ml}$ of $0,1 \mathrm{~N} \mathrm{H}_{2} \mathrm{SO}_{4}$ were added to the mixture and shaken again. The upper phase is transferred to another flask, that contains $25 \mathrm{ml}$ of $0,01 \mathrm{~N} \mathrm{H}_{2} \mathrm{SO}_{4}$, shaken again. The upper heptane fraction is separated and titrated as described above. It was shown that BSA A1470 Sigma Cohn Analog ${ }^{\mathrm{TM}}$ possesses only 15\%-binding capability, while Fatty Acid Free-BSA MP Biomedicals, LLC - 87,5\% (of the maximum possible) (table 2).

Thus, addition of BSA (Cohn An.), possessing only $15 \%$ (moles) binding capability of the maximum possible, result in the formation of nonculturable cells. Remaining $15 \%$ is necessary for the binding of $57,3 \mu \mathrm{M}$ of FA, incorporated together with Tween 80 . Therefore we may conclude that 33-59 $\mu \mathrm{M}$ of free FA found in the medium can't be bound with BSA, and as the result have to be accumulated in culture liquid, which may lead to the formation of nonculturable cells in response to stressful conditions. As it was mentioned earlier, these FA have biogenic nature, and might be the product of Tween 80 hydrolysis.

In the case of more pure BSA (MP Biomedicals, LLC) it is obvious that despite the presence of free FA in Tween 80 and negligible traces in BSA, it is still capable of binding up to 205,2 $\mu \mathrm{M}$ of FA (i.e. $68,4 \%$ of maximum possible $300 \mu \mathrm{M}$ ). Therefore FA, that might be secreted during the lifetime of mycobacterial cells are removed from them with BSA, which enables more successful adaptation to stressful conditions, and dormant cells do not form.

Thus in conducted experiments we demonstrated secretion of lipid substances including FA into surrounding medium during growth upon stressful conditions which results in transition of bacilli into dormant state. Moreover extracellular FA are accumulated in this process. 


\begin{tabular}{|c|c|c|}
\hline \multicolumn{2}{|c|}{ Component of the medium } & Concentration in culture liquid, $\mu \mathrm{M}$ \\
\hline \multicolumn{2}{|c|}{ Tween 80} & 382 \\
\hline \multicolumn{2}{|c|}{ Admixed FA in Tween 80} & 57.3 \\
\hline \multicolumn{2}{|c|}{ Percentage of admixed FA in Tween 80} & $\begin{array}{c}15 \% \\
(57.3 \cdot 100 \% / 382)\end{array}$ \\
\hline \multicolumn{2}{|c|}{ Maximum binding capacity of BSA at $\mathrm{pH} 6,6-7^{*}$} & 300 \\
\hline \multicolumn{2}{|c|}{ BSA (Cohn An.) } & 75 \\
\hline \multicolumn{2}{|c|}{ FA bound with BSA (Cohn An.) } & 255 \\
\hline \multicolumn{2}{|c|}{ Binding capacity of BSA (Cohn An.) } & $\begin{array}{c}15 \% \\
((300-255) \cdot 100 \% / 300)\end{array}$ \\
\hline \multicolumn{2}{|l|}{ BSA (MP) } & 75 \\
\hline \multicolumn{2}{|c|}{ FA bound with BSA (MP) } & 37.5 \\
\hline \multicolumn{2}{|c|}{ Binding capacity of BSA (MP) } & $\begin{array}{c}87.5 \% \\
((300-37.5) \cdot 100 \% / 300)\end{array}$ \\
\hline \multirow{3}{*}{$\begin{array}{l}\text { Free FA in growth } \\
\text { medium }\end{array}$} & $24 \mathrm{~h}$. & 33.2 \\
\hline & $48 \mathrm{~h}$. & 41.4 \\
\hline & $72 \mathrm{~h}$. & 59 \\
\hline
\end{tabular}

* Maximum binding capability of BSA (FA mole / BSA mole) was shown to be $\sim 4$ [Spector, 1969].

Table 2. Amounts of FA introduced into growth medium along with Tween 80 and BSA with consideration of experimentally used concentrations. Amounts of free FA detected in growth medium.

It is well known that $M$. smegmatis and $M$. tuberculosis dormant cells can be reactivated with resuscitation promoting factor (Rpf) [Shleeva, 2004; Shleeva, 2011]. An influence of FA on resuscitation appears to be interesting in the context of the shown data on their role in the process of adaptation to stressful conditions.

\subsection{An effect of lipid substances on reactivation of mycobacterial dormant cells}

M. smegmatis dormant nonculturable cells have been studied to be reactivated by their incorporation into fresh medium containing potassium ions and various lipid substances (triacylglycerols, PL, FA) [Nazarova, 2011]. Oleic acid is observed to have the strongest resuscitation effect, and its active concentrations are 0.18-10.6 $\mu \mathrm{M}$. Such low concentration range sufficient for reactivation of dormant cells indicates a signal function of this FA in resuscitation.

The capability of phospholipids to stimulate growth of $\mathrm{M}$. tuberculosis cells in the late stationary phase was known previously [Zhang, 2001]. Since FA are components of PL, we supposed that both phospholipids and FA may be able to stimulate reactivation of dormant cells. To study the role of the lipid compounds in resuscitation process, nonculturable cells were transferred into fresh medium containing potassium ions and a certain amount of lipid component, which effect on cell reactivation was estimated by the method of final dilutions.

As it was found different types of lipids are objectively capable to "trigger" the process of resuscitation of nonculturable cells. Addition of oleic acid compared to different length acids, higher alcohols, and TAG in concentration of $1 \mu \mathrm{g} / \mathrm{ml}$ to $10^{6}$ nonculturable cells was the most efficient for reactivation (Fig. 10). The phospholipid and oleic acid effects on 
resuscitation were concentration dependent (Fig. 11). It is important that the oleic acid concentrations $(0.05-3 \mu \mathrm{g} / \mathrm{ml})$ were in significantly lower range compared to phospholipids $(50-250 \mu \mathrm{g} / \mathrm{ml})$ (Fig. 11). Such low concentration excludes the use of free FA in this process as a nutrient source, and that they are the substances responsible for reactivation, while phospholipids serve as their sources (due to activity of bacterial phospholipases). FA are known to function as signal substances in a number of important processes in bacterial cells. Thus, arachidonic acid serves as chemoattractant for Dictyostelium discoideum [Schaloske, 2007]. Another example of FA signal function is their secretion into extracellular space by the Xanthomonas campestris, plant pathogen, and their following absorption resulting in increased expression of genes associated with cell pathogenicity [Barber, 1997]. So, we have revealed a new, not previously described signal function of oleic acid as an agent stimulating reactivation of nonculturable mycobacterial forms.

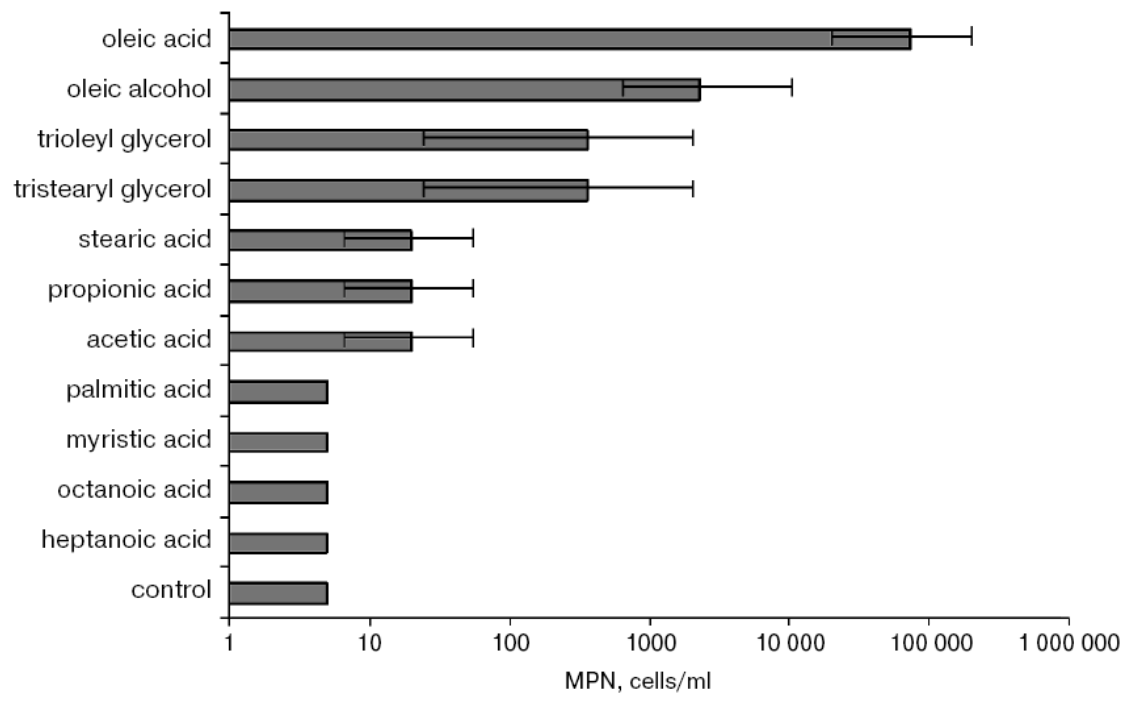

Fig. 10. Effect of FA and substances of lipid nature (in concentration of $1 \mu \mathrm{g} / \mathrm{ml}$ ) on resuscitation of M. smegmatis nonculturable cells. Represented from [Nazarova, 2011].
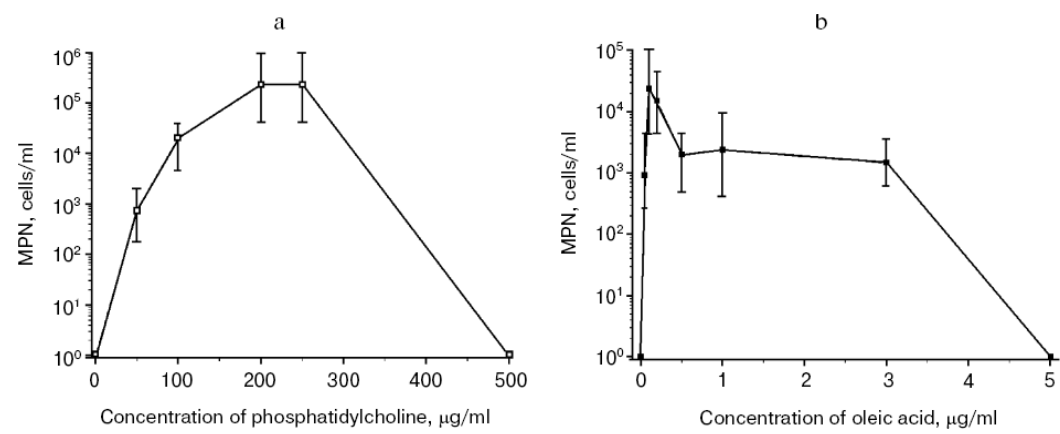

Fig. 11. Effect of phosphatidylcholine (a) and oleic acid (b) in different concentrations on resuscitation of M. smegmatis nonculturable cells. Represented from [Nazarova, E.V., 2011]. 
All of the presented results support an idea that amount of FA in surrounding medium play a determinative role in formation and reactivation of $M$. smegmatis nonculturable cells (fig. 12). Thus $0.18-10.6 \mu \mathrm{M}$ of oleic acid possess a resuscitation effect. A little larger number of FA (33-59 $\mu \mathrm{M})$ accumulates in culture liquid during transition into nonculturable state. And finally, as it was shown previously, oleic acid in amount of $92 \mu \mathrm{M}$ inhibits growth of mycobacterial cells.

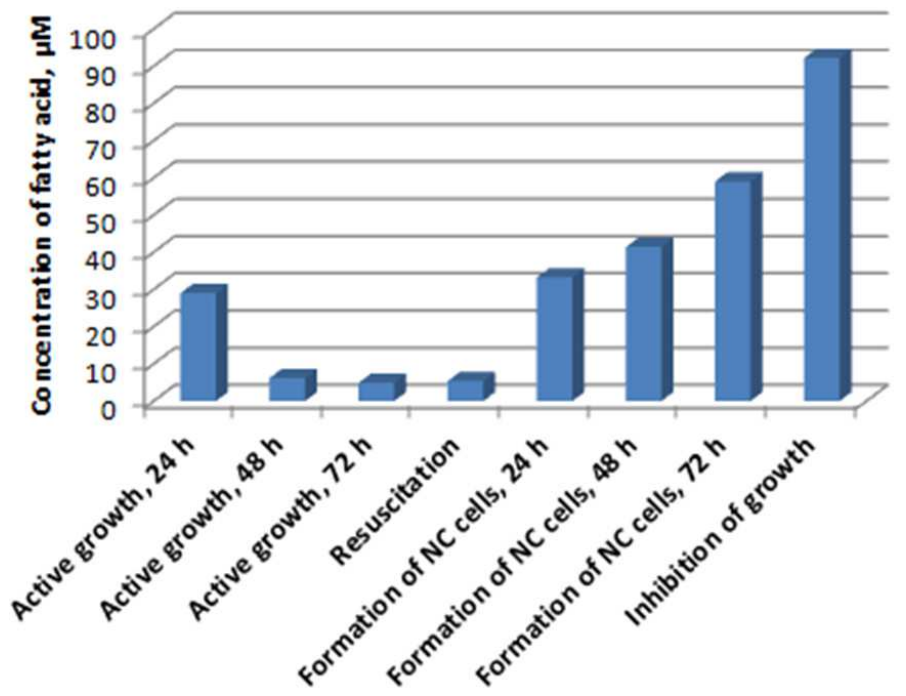

Fig. 12. Correlation between a state of M. smegmatis and a quantity of extracellular FA.

\section{Conclusion}

Pathogen M. tuberculosis by itself as well as particular bacterial lipids are reported to induce loading of macrophages with lipid bodies resulting in formation of foamy macrophages [Russell, 2009]. So it seems that mycobacterial lipids passed by macrophages to each other cause such differentiation of immune cells influencing on total tissue remodelling of the infection site. Inside of such altered foamy macrophages mycobacteria have an access and actually use host lipids from the lipid drops, which leads to their transition into a state similar to the nonreplicating state [Peyron, 2008]. Cultivation of mycobacteria in medium enriched with lipid substances showed that bacilli do form cells with changed morphology and resistant to anti-tuberculosis drugs in such conditions [Nazarova, 2010].

When as a consequence of total 'lipidation' of granuloma macrophages mycobacteria find themselves in the excess of surrounding lipids, this excess induces a dormant state in pathogens. If immune system of the host is active enough, granuloma either undergoes resolution, or remains balanced. But in case of active disease development caseum is accumulated in the centre of some granulomas; this leads to necrosis and collapse of granuloma, and to release of virulent bacilli into airways [Kaplan, 2003]. Since during this release mycobacteria appear to be finally not in stressful conditions and not surrounded or surrounded with a little amount of lipid substances, they might reactivate, as it can be 
supported by our results where only $0.18-10.6 \mu \mathrm{M}$ of oleic acid is required for resuscitation of dormant bacilli.

\section{Acknowledgment}

The authors acknowledge Dr. Arseny S. Kaprelyants and his laboratory at Bach Institute of Biochemistry (Russian Academy of Sciences), and Dr. Larisa N. Chernousova's research group at Central TB research Institute (Russian Academy of Medical Sciences) for consistent and efficient collaboration.

\section{References}

Abramovitch, R.B., Rohde K.H., Hsu, F.F., \& Russell, D.G. (2011). aprABC: a Mycobacterium tuberculosis complex-specific locus that modulate $\mathrm{pH}$-driven adaptation to the macrophage phagosome. Mol.Microbiol., Vol. 80, No. 3, (May 2011), pp. 678-694

Andreevskaya, S.N., Smirnova, T.G., Zhogina, Yu.A., Smirnova, D.I., Mikulovich, J.L, Kalashnikova, T.Yu., Sorokoumova, G.M., Selishcheva, A.A., Chernousova, L.N., \& Shvets, V.I. (2010). Effect of exogenous cardiolipin on the growth and viability of Mycobacterium tuberculosis H37Rv in vitro. Dokl. Biol. Sci., Vol. 434, No. 5, (October 2010), pp. 371-374

Barber, C.E., Tang, J.L., Feng, J.X., Pan, M.Q., Wilson,T.J.G., Slater, H., Dow, J.M., Williams, P., \& Daniels, M.J. (1997). A novel regulatory system required for pathogenicity of Xanthomonas campestris is mediated by a small diffusible signal molecule. Mol. Microbiol., Vol. 24, No. 3, (May 1997), pp. 555-566

Boshoff, H.I., Myers, T.G., Copp, B.R., McNeil, M.R., Wilson, M.A., \& Barry III, C.E. (2004). The transcriptional responses of Mycobacterium tuberculosis to inhibitors of metabolism: novel insights into drug mechanisms of action. J. Biol. Chem., Vol. 279, No. 38, (September 2004), pp. 40174-40184

Carman, G.M., \& Henry, S.A. (2007). Phosphatidic acid plays a central role in the transcriptional adaptational regulation of glycerophospholipid synthesis in Sacchatomyces cerevisiae. J. Biol. Chem., Vol. 282, No. 52, (November 2007), pp. 3729337297

Chen, R.F. (1967). Removal of Fatty Acids from Serum Albumin by Charcoal Treatment. The Journal of Biological Chemistry, Vol. 242, No. 2, (January 1967), pp. 173-181

Cole, S.T., Brosch, R., Parkhill, J., Garnier, T., Churcher, C., Harris, D., Gordon, S.V., Eiglmeier, K., Gas, S., Barry, C.E. 3rd, Tekaia, F., Badcock, K., Basham, D., Brown, D., Chillingworth, T., Connor, R., Davies, R., Devlin, K., Feltwell, T., Gentles, S., Hamlin, N., Holroyd, S., Hornsby, T., Jagels, K., Krogh, A., McLean, J., Moule, S., Murphy, L., Oliver, K., Osborne, J., Quail, M.A., Rajandream, M.A., Rogers, J., Rutter, S., Seeger, K., Skelton, J., Squares, R., Squares, S., Sulston, J.E., Taylor, K., Whitehead, S., \& Barrell, B.G. (1998). Deciphering the biology of Mycobacterium tuberculosis from the complete genome sequence. Nature, Vol. 393, No. 6685, (June 1998), pp.537-544

Deb, C., Daniel, J., Sirakova, T.D., Abomoelak, B., Dubey, V.S., \& Kolattukudy, P.E. (2006). A novel lipase belonging to the hormone-sensitive lipase family induced under starvation to utilize stored triacylglycerol in Mycobacterium tuberculosis. J. Biol. Chem., Vol. 281, No. 7, (February 2006), pp. 3866-3075 
Dole, V.P. (1956). A relation between non-esterified fatty acids in plasma and the metabolism of glucose. J. Clin. Invest., Vol. 35, No. 2, (February 1956), pp. 150-154

Fenhalls, G., Stevens, L., Moses, L., Bezuidenhout, J., Betts, J.C., Helden Pv.P., Lukey, P.T., \& Duncan, K. (2002). In situ detection of Mycobacterium tuberculosis transcripts in human lung granulomas reveals differential gene expression in necrotic lesions. Infect Immun., Vol. 70, No. 11, (November 2002), pp.6330-6338

Kanetsuna, F. (1985). Bactericidal effect of fatty acids on mycobacteria, with particular reference to the suggested mechanism of intracellular killing. Microbiol Immunol., Vol. 29, No. 2, pp.127-141

Kaplan, G., Steyn, L.M., Bekker, L.G., Post, F.A., \& Wainwright, H.C. (2003). Mycobacterium tuberculosis growth at the cavity surface: a microenvironment with failed immunity. Infect. Immun., Vol. 71, No. 12, (December 2003), pp. 7099-7108

Kondo, E., \& Kanai, K. (1976). An attempt to cultivate mycobacteria in simple synthetic liquid medium containing lecithin-cholesterol liposomes. Jpn. J. Med. Sci. Biol, Vol. 29, No. 3, (June 1976), pp.109-121

Kondo, E., \& Kanai, K. (1985). Mechanism of bactericidal activity of lysolecithin and its biological implication. Jpn. J. Med. Sci. Biol, Vol. 38, No. 4, (August 1985), pp.181-194

Lu, Y., Wu, Y.R., \& Han, B. (2005). Anaerobic induction of isocitrate lyase and malate synthase in submerged rice seedlings indicates the important metabolic role of the glyoxylate cycle. Acta Biochim. Biophys. Sin. (Shanghai), Vol. 37, No. 6, (June 2005), pp.406-414

McKinney, J.D., Honer zu Bentrup, K., Munoz-Elias, E.J., Miczak, A., Chen, B., Chan, W.T., Swenson, D., Sacchettini, J.C., Jacobs, Jr. W.R., \& Russell, D.G. (2000). Persistence of Mycobacterium tuberculosis in macrophages and mice requires the glyoxylate shunt enzyme isocitrate lyase. Nature, Vol. 406, No. 6797, (August 2000), pp. 735-738

Mikulovich, J.L., Andreevskaya, S.N., Smirnova, T.G., Sorokoumova, G.M., Chernousova, L.N., Selishcheva, A.A., \& Shvets, V.I. (2010). The influence of cardiolipin liposomes on growth and survival of Mycobacterium tuberculosis H37Rv in vitro, Proceedings of The Moscow International Scientific and Practical Conference "Biotechnology: Ecology of Big Cities", Moscow, Russia, March 15-17, 2010, pp. 453454

Mishra, K.C., de Chastellier, C., Narayana, Y., Bifani, P., Brown, A.K., Besra, G.S., Katoch, V.M., Joshi, B., Balji, K.N., \& Kremer, L. (2008). Functional role of the PE domain immunogenicity of the Mycobacterium tuberculosis triacylglycerol hygrolase LipY. Infect Immun, Vol. 76, No. 1, (January 2008), pp. 127-140

Mizushima, T., Natori, S., \& Sekimizu, K. (1992). Inhibition of Escherichia coli DNA topoisomerase I activity by phospholipids. Biochem. J., Vol. 285, Part. 2, (July 1992), pp. 503-506

Morris, R. P., Nguyen, L., Gatfield, J., Visconti, K., Nguyen, K., Schnappinger, D., Ehrt, S., Liu, Y., Heifets, L., Pieters, J., Schoolnik, G., \& Thompson, C.J. (2005). Ancestral antibiotic resistance in Mycobacterium tuberculosis. Proc. Natl. Acad. Sci. U.S.A., Vol. 102, No. 34, (August 2005), pp. 12200-12205

Munoz-Elias, E.J., \& McKinney, J.D. (2005). Mycobacterium tuberculosis isocitrate lyases 1 and 2 are jointly required for in vivo growth and virulence. Nature Med., Vol. 11, No. 6, (June 2005), pp. 638-644 
Nazarova, E.V., Zhogina, Y.A., Morozova, N.S., Shleeva, M.O., Sorokoumova, G.M., Selischeva, A.A., Kaprelyants, A.S., \& Shvets, V.I. (2010) The Influence of carbon source on antituberculous drug resistance of mycobacteria, Proceedings of The Moscow International Scientific and Practical Conference "Biotechnology: Ecology of Big Cities", Moscow Russia, March 15-17, 2010, pp. 454-455

Nazarova, E.V., Shleeva, M.O., Morozova, N.S., Kudykina, Yu.K., Vostroknutova, G.N., Ruzhitsky, A.O., Selishcheva, A.A., Sorokoumova, G.M., Shvets, V.I., \& Kaprelyants A.S. (2011). Role of lipid components in formation and reactivation of Mycobacterium smegmatis "nonculturable" cells. Biochemistry (Moscow), Vol. 76, No. 6, (June 2011), pp. 636-644

Peyron, P., Vaubourgeix, J., Poquet, Y., Levillain, F., Botanch, C., Bardou, F., Daffé, M., Emile, J.F., Marchou, B., Cardona, P.J., de Chastellier, C., \& Altare, F. (2008). Foamy macrophages from tuberculous patients' granulomas constitute a nutrient-rich reservoir for M. tuberculosis persistence. PLoS Pathog., Vol. 4, No. 11, (November 2008), pp. e1000204

Raynaud, C., Guilhot, C., Rauzier, J., Bordat, Y., Pelicic, V., Manganelli, R., Smith, I., Gicquel, B., \& Jackson M. (2002). Phospholipases C are involved in the virulence of Mycobacterium tuberculosis. Mol. Microbiol., Vol. 45, No. 1, (July 2002), pp. 203-217

Russell, D.G., Cardona, P.-J., Kim, M.-J., Allain, S., \& Altare F. (2009). Foamy macrophages and the progression of the human tuberculosis granuloma. Nature Immunology, Vol. 10, No. 9, (September 2009), pp. 943 - 948

Russell, D.G., VanderVen, B.C., Lee, W., Abramovitch, R.B., Kim, M.J., Homolka, S., Niemann, S., \& Rohde, K.H. (2010). Mycobacterium tuberculosis wears what it eats. Cell Host Microbe, Vol. 8, No. 1, (July 2010), pp. 68-76

Schaloske, R.H., Blaesius, D., Schlatterer, C., \& Lusche, D.F. (2007). Arachidonic acid is a chemoattractant for Dictyostelium discoideum cells. J. Biosci., Vol. 32, No. 7, (December 2007), pp. 1281-1289

Schnappinger, D., Ehrt, S., Voskuil, M.I., Liu, Y., Mangan, J.A., Monahan, I.M., Dolganov, G., Efron, B., Butcher, P.D., Nathan, C., \& Schoolnik, G.K. (2003). Transcriptional adaptation of Mycobacterium tuberculosis within macrophages: insights into the phagosomal environment. J. Exp. Med., Vol. 198, No. 5, (September 2003), pp. 693704

Shakina, Y.V., Troshkina, O.A., Petrova, E.E., Salina, E.G., Sorokoumova, G.M., Shvets, V.I., Kaprelyants, A.S., \& Selishcheva, A.A. (2007). Susceptibility of Mycobacterium smegmatis, grown on the media, contained various carbon substrates, to antituberculosis drugs. Zh. Mikrobiol. (Moscow), No. 6, pp. 7-11

Shleeva, M., Mukamolova, G.V., Young, M., Williams, H.D., \& Kaprelyants, A.S. (2004). Formation of 'non-culturable' cells of Mycobacterium smegmatis in stationary phase in response to growth under suboptimal conditions and their Rpf-mediated resuscitation. Microbiology, Vol. 150, Pt. 6, (June 2004), pp. 1687-1697

Shleeva, M.O., Kudykina, Y.K., Vostroknutova, G.N., Suzina, N.E., Mulyukin, A.L., \& Kaprelyants, A.S. (2011). Dormant ovoid cells of Mycobacterium tuberculosis are formed in response to gradual external acidification. Tuberculosis (Edinb), Vol. 91, No. 2, (March 2011), pp. 146-154

Smirnova, T.G., Mikulovich, J.L., Andreevskaya, S.N., Sorokoumova, G.M., Chernousova, L.N., Selishcheva, A.A., \& Shvets V.I. (2011). Cardiolipin lysoderivatives suppress 
the survival both susceptible and resistant strains of Mycobacterium tuberculosis. Russian Journal of Biopharmaceuticals, Vol. 3, No. 2, pp. 19-27

Sorokoumova, G.M., Andreevskaya, S.N., Smirnova, T.G., Petrova, E.E., Zhogina, Yu.A., Kalashnikova, T.Yu., Chernousova, L.N., Selishcheva, A.A., \& Shvets V.I. (2009). Effects of liposomes of different lipid composition on in vitro growth of Mycobacterium tuberculosis H37Rv. Bull Exp Biol Med, Vol. 148, No. 5, (November 2009), pp. 550-552

Spector, A.A., John, K., \& Fletcher, J.E. (1969). Binding of long-chain fatty acids to bovine serum albumin. Journal of Lipid Research, Vol. 10, No. 1, (January 1969), pp. 56-67

Stonehouse, M.J., Cota-Gomez, A., Parker, S.K., Martin, W.E., Hankin, J.A., Murphy, R.C., Chen, W., Lim, K.B., Hackett, M., Vasil, A.I., \& Vasil, M.L. (2002). A novel class of microbial phosphocholine -specific phospholipases C. Mol Microbiol, Vol. 46, No. 3, (November 2002), pp. 661-676

Sung, N., Takayama, K., \& Collins, M.T. (2004). Possible association of GroES and antigen 85 proteins with heat resistance of Mycobacterium paratuberculosis. Appl. Environmental Microbiol, Vol. 70, No. 3, (March 2004), pp. 1688-1697

Takayama, K., Wang, L., \& David, H.L. (1972). Effect of isoniazid on the in vivo mycolic acid synthesis, cell growth, and viability of Mycobacterium tuberculosis. Antimicrob Agent Chemother, Vol. 2, No. 1, (July 1972), pp. 29-35

Wehrli, W., \& Staehelin, M. (1971). Actions of the rifamycins. Bacteriological Reviews, Vol. 35, No. 3, (September 1971), pp. 290-309

Yamamoto, K., Muniruzzaman, S., Rajagopalan, M., \& Madiraju, M.V. (2002). Modulation of Mycobacterium tuberculosis DnaA protein-adenine-nucleotide interactions by acidic phospholipids. Biochem J., Vol. 363, Pt. 2, (April 2002), pp.305-311

Zhang, Y., Yang, Y., Woods, A., Cotter, R.J., \& Sun, Z. (2001). Resuscitation of dormant Mycobacterium tuberculosis by phospholipids or specific peptides. Biochem. Biophys. Res. Commun., Vol. 284, No. 2, (June 2001), 542-547 


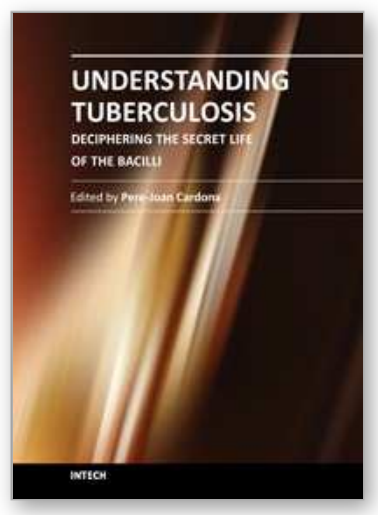

\author{
Understanding Tuberculosis - Deciphering the Secret Life of the \\ Bacilli \\ Edited by Dr. Pere-Joan Cardona
}

ISBN 978-953-307-946-2

Hard cover, 334 pages

Publisher InTech

Published online 17, February, 2012

Published in print edition February, 2012

Mycobacterium tuberculosis, as recent investigations demonstrate, has a complex signaling expression, which allows its close interaction with the environment and one of its most renowned properties: the ability to persist for long periods of time under a non-replicative status. Although this skill is well characterized in other bacteria, the intrinsically very slow growth rate of Mycobium tuberculosis, together with a very thick and complex cell wall, makes this pathogen specially adapted to the stress that could be generated by the host against them. In this book, different aspects of these properties are displayed by specialists in the field.

\title{
How to reference
}

In order to correctly reference this scholarly work, feel free to copy and paste the following:

Alla A. Selishcheva, Galina M. Sorokoumova and Evgeniya V. Nazarova (2012). Lipid Surrounding of Mycobacteria: Lethal and Resuscitating Effects, Understanding Tuberculosis - Deciphering the Secret Life of the Bacilli, Dr. Pere-Joan Cardona (Ed.), ISBN: 978-953-307-946-2, InTech, Available from:

http://www.intechopen.com/books/understanding-tuberculosis-deciphering-the-secret-life-of-the-bacilli/lipidsurrounding-of-mycobacteria-lethal-and-resuscitating-effects

\section{INTECH}

open science | open minds

\section{InTech Europe}

University Campus STeP Ri

Slavka Krautzeka 83/A

51000 Rijeka, Croatia

Phone: +385 (51) 770447

Fax: +385 (51) 686166

www.intechopen.com

\section{InTech China}

Unit 405, Office Block, Hotel Equatorial Shanghai

No.65, Yan An Road (West), Shanghai, 200040, China

中国上海市延安西路65号上海国际贵都大饭店办公楼405单元

Phone: +86-21-62489820

Fax: +86-21-62489821 
(C) 2012 The Author(s). Licensee IntechOpen. This is an open access article distributed under the terms of the Creative Commons Attribution 3.0 License, which permits unrestricted use, distribution, and reproduction in any medium, provided the original work is properly cited. 